\title{
Promoter Transgenics Reveal Multiple Gonadotropin-Releasing Hormone-I-Expressing Cell Populations of Different Embryological Origin in Mouse Brain
}

\author{
Michael J. Skynner, Ruth Slater, Joan A. Sim, Nick D. Allen, and Allan E. Herbison \\ Laboratories of Neuroendocrinology and Developmental Neurobiology, The Babraham Institute, Cambridge CB2 4AT, \\ United Kingdom
}

\begin{abstract}
Gonadotropin-releasing hormone-l (GnRH-I) is thought to be expressed by a single, highly spatially restricted group of neurons, which originate in the olfactory placode and migrate through the nose into the medial septum and hypothalamus from where they control fertility. Transgenic mice bearing a 13.5 $\mathrm{kb} \mathrm{GnRH}-\mathrm{l}-\mathrm{lacZ}$ reporter construct were derived and found to express high levels of $\beta$-galactosidase mRNA and protein within the septohypothalamic $\mathrm{GnRH}$ neurons in a correct temporal and spatial manner. Unexpectedly, low levels of $\beta$-galactosidase were also present in three further populations of cells within the lateral septum, bed nucleus of the stria terminalis, and tectum. Analysis of wild-type mice with three different $\mathrm{GnRH}-\mathrm{I}$ antibodies revealed distinct and transient patterns of $\mathrm{GnRH}-\mathrm{I}$ peptide expression during development in all three of these populations revealed by transgenics. The synthesis of $\mathrm{GnRH}$ by cells of the lateral septum was the most
\end{abstract}

persistent and remained until the third postnatal week. Embryonic "small eye" Pax-6 null mice, which fail to develop an olfactory placode, were also examined and shown to have equivalent populations of $\mathrm{GnRH}$-I-immunoreactive cells in the lateral septum, tectum, and bed nucleus of the stria terminalis but none of the migrating cells that form the septohypothalamic $\mathrm{GnRH}$ population. These results prove that so-called "ectopic" expression in promoter transgenic lines can reflect authentic developmental patterns of gene expression. They further provide the first demonstration in mammalian brain that multiple neuronal populations of different embryological origin express $\mathrm{GnRH}-\mathrm{I}$ peptide during embryonic and postnatal development.

Key words: $\beta$-galactosidase; development; gonadotropinreleasing hormone; luteinizing hormone-releasing hormone; mouse; Pax-6; promoter transgenics; septum
A variety of experimental approaches have demonstrated that the neuropeptide gonadotropin releasing-hormone $(\mathrm{GnRH})$ is expressed in a highly restricted group of neurons within the mammalian brain (Silverman et al., 1994). These cells are known to originate in the olfactory placode and migrate through the nasal septum and forebrain to reside, principally, within the medial septum and hypothalamus (Schwanzel-Fukuda and Pfaff; 1989; Wray et al., 1989). It is equally well established that the majority of these septohypothalamic GnRH neurons project to the median eminence, from where they control the activity of pituitary gonadotrophs and, thus, represent the final output neurons of the neural network regulating fertility (Silverman et al., 1994). Evidence also suggests a role for GnRH in the regulation of mammalian sexual behavior (Moss and McCann, 1973; Pfaff, 1973).

Although an equivalent septohypothalamic population of GnRH neurons is present in nonmammalian taxa, a second form of GnRH was discovered in some of these species and shown to be expressed by a population of cells located in the midbrain (Muske, 1993; Sherwood et al., 1993; Tobet et al., 1997). The conservation and expression of this second form, now termed

\footnotetext{
Received Jan. 19, 1999; revised April 9, 1999; accepted May 7, 1999.
}

This work was supported by the Lister Institute of Preventive Medicine and the Biotechnology and Biological Sciences Research Council. We thank Dr. A Mason for providing the GnRH-SmaI plasmid and Drs. A. Caraty, R. Benoit, N Sherwood, and S. Wray for generous gifts of antibodies. We thank members of the Babraham Institute Small Animal Facility for their valued assistance and Dr. A. Woodhouse for early discussions. This work was presented in part at the 27th Annual Meeting of the Society for Neuroscience, New Orleans, 1997.

Correspondence should be addressed to Dr. Allan E. Herbison, Laboratory of Neuroendocrinology, Babraham, Cambridge CB2 4AT, UK.

Copyright (C) 1999 Society for Neuroscience $0270-6474 / 99 / 195955-12 \$ 05.00 / 0$
GnRH-II, have recently been demonstrated in the midbrain of the monkey, but curiously not the rodent, and the human gene has been cloned (Lescheid et al., 1997; White et al., 1998). Thus, at least two forms of GnRH exist in the mammalian brain; GnRH-I, which is expressed by a restricted group of midline septohypothalamic neurons of olfactory origin that control reproduction, and GnRH-II, which is synthesized in midbrain cells of likely local origin but unknown function.

One of the great practical difficulties in trying to characterize GnRH-I neurons is that they do not lie within a specific region of the brain but, rather, lie scattered throughout the medial septum, preoptic area, and basal hypothalamus of the mammalian brain (Silverman et al., 1994). To try and address this problem, we have initiated a program of research that involves the targeting of the GnRH-I neurons with promoter-driven transgenics in vivo in the mouse. We report here the first surprising result of these studies in that not one but four cell populations in the brain are found to express the $\beta$-galactosidase ( $\beta$ gal) reporter when driven by 13.5 $\mathrm{kb}$ of GnRH-I genomic sequences. Follow-up investigations in transgenic and wild-type mice have demonstrated that all four populations of neurons synthesize authentic GnRH-I, and work in Pax-6 null mice has revealed a differing embryological origin for the three newly identified populations compared with that of the classic septohypothalamic GnRH-I neurons.

\section{MATERIALS AND METHODS}

\section{Production of GnRH-LacZ transgenic mice}

A GnRH reporter construct was assembled by inserting a $3 \mathrm{~kb}$

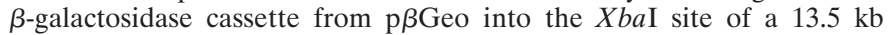
genomic clone (pGnRHSmaI; gift of Dr. A. Mason, Prince Henry's 
Institute, Melbourne, Australia), which contained all introns and exons as well as $5 \mathrm{~kb}$ of $5^{\prime}$ - and $3.5 \mathrm{~kb}$ of $3^{\prime}$-flanking sequences of murine GnRH. The ATG start site for GnRH transcription of this plasmid had been mutated to TTG and a SmaI restriction site introduced between sequences coding for amino acids 2 and 3 of the GnRH decapeptide. For microinjection, the construct was excised from the vector (pSP65) using SalI and BstEII double digestion, separated by agarose gel electrophoresis, and gel-purified using Glassmilk (Qiagen, Hilden, Germany). DNA was further purified using an Amicon (Beverly, MA) 30 micopure/ microcon microconcentrator. DNA concentration was estimated by reference to DNA concentration standards after agarose gel electrophoresis and diluted to a final injection concentration of $2.5 \mathrm{ng} / \mu 1$ in $10 \mathrm{~mm}$ Tris-HCl, $\mathrm{pH} 7.4$, and $0.1 \mathrm{~mm}$ EDTA.

All mice were bred and housed at The Babraham Institute according to UK Home Office requirements under projects $80 / 972$ and $80 / 1005$, and transgenic mice were produced by pronuclear injection (Hogan et al., 1994). Briefly, fertilized mouse eggs from superovulated F1 mice $(\mathrm{CBA} \times \mathrm{C} 57 / \mathrm{B} 16)$ mated to $\mathrm{F} 1$ males were visualized using differential interference contrast optics on an inverted Nikon (Tokyo, Japan) microscope. DNA was introduced into the male pronucleus using Leitz (Wetzlar, Germany) manual micromanipulators and glass capillary micropipettes. Eggs were cultured overnight to the two-cell stage and subsequently transferred to the oviducts of pseudopregnant F1 recipient female mice.

Transgenic mice were identified by either Southern blot or PCR analysis of genomic DNA isolated from tail biopsies. For the former, 0.5 $\mathrm{cm}$ of tail was removed from mice after weaning under general anesthesia and digested overnight at $55^{\circ} \mathrm{C}$ in lysis buffer containing $100 \mathrm{~mm}$ Tris$\mathrm{HCl}, \mathrm{pH}$ 8.5, 5 mм EDTA, $\mathrm{pH}$ 8.0, 0.2\% SDS, $200 \mathrm{~mm} \mathrm{NaCl}$, and 100 $\mu \mathrm{g} / \mathrm{ml}$ Proteinase K (Sigma, Poole, UK). Undigested material was removed by centrifugation, and the supernatant was extracted with an equal volume of phenol-chloroform. Genomic DNA was precipitated by the addition of an equal volume of isopropanol and spooled into $200 \mu \mathrm{l}$ of Tris-EDTA buffer (10 mM Tris-HCl, $\mathrm{pH}$ 8.0, and 1 mM EDTA). Thirty microliters of DNA were then digested overnight with EcoRI, and fragments were resolved on horizontal $0.8 \%$ agarose gels. After transfer to a Hybond $\mathrm{N}+$ membrane, by alkali capillary blotting, membranes were hybridized in Church buffer $(0.5 \mathrm{~m}$ phosphate buffer, $\mathrm{pH} 7.5,7 \%$ SDS, and $1 \mathrm{mM}$ EDTA) overnight with a random-primed $\left[\alpha{ }^{32} \mathrm{P}\right] \mathrm{dCTP}$ (ICNFlow)-labeled $3.0 \mathrm{~kb}$ SmaI fragment spanning the entire $\beta$-galactosidase gene, isolated from $\mathrm{p} \beta$-Geo. Hybridization was performed at $65^{\circ} \mathrm{C}$ in a rotary oven (Hybaid). After hybridization, the filters were washed in Church wash (40 mm phosphate buffer and 1\% SDS) three times for 10 min each, wrapped in Saran wrap (DuPont, Wilmington, DE), and exposed to x-ray film (X-OMAT; Kodak, Rochester, NY) using intensifying screens at $-70^{\circ} \mathrm{C}$.

For PCR identification, Lac-ZMF (5'-CCACGGCCACCGATATTATTTGCCCG-3') and Lac-ZMR (5'-TTTTGCTTCCGTCAGCGCTGGATGCG-3') primers were used to amplify a 410 bp fragment from the $\beta$-galactosidase gene in individual $25 \mu \mathrm{l}$ reactions containing $50 \mathrm{~mm} \mathrm{KCl}$, $10 \mathrm{~mm}$ Tris- $\mathrm{HCl}$, pH 9.0, $1.5 \mathrm{~mm} \mathrm{MgCl}_{2}, 0.2 \mu \mathrm{M}$ dNTPs, $1 \mu \mathrm{M}$ each, 0.6 U of Taq DNA polymerase (Pharmacia), and $0.5 \mu$ l of genomic DNA. PCR was performed in a Robocycler (Stratagene, La Jolla, CA) as follows: $95^{\circ} \mathrm{C}$ for $3 \mathrm{~min}, 60^{\circ} \mathrm{C}$ for $1 \mathrm{~min}$, and $72^{\circ} \mathrm{C}$ for $2 \mathrm{~min}$ for one cycle, followed by 24 cycles of $95^{\circ} \mathrm{C}$ for $40 \mathrm{sec}, 60^{\circ} \mathrm{C}$ for $35 \mathrm{sec}$, and $72^{\circ} \mathrm{C}$ for 50 sec. Amplicons were resolved on $1.5 \%$ horizontal agarose gels, visualized using ethidium bromide staining, and photographed using a gel documentation system (Bio-Rad, Hercules, CA).

\section{Immunocytochemical analysis}

Antibodies. A polyclonal rabbit antibody (55976; ICN Biomedicals $\mathrm{GmbH}$, Postfach, Germany) raised against $\beta$ gal from Escherichia coli was used to detect transgene expression (Min et al., 1994). Three different polyclonal rabbit antibodies specific for GnRH-I were used for peroxidase immunostaining: LR1 (a gift from R. Benoit, McGill University, Montreal, Canada) raised against [D-lys $\left.{ }^{6}\right]-G n R H-I$, which detects amino acids $6-10$ of both the precursor and amidated decapeptide (Silverman et al., 1990); SW1 (a gift from S. Wray, National Institute of Neurological Diseases and Stroke) raised against mammalian GnRH-I (Wray et al., 1988); and GF6 (a gift from Dr. N. Sherwood, University of Victoria, Victoria, Canada) raised against synthetic salmon $\left[\operatorname{Trp}^{7}\right.$-Leu $\left.^{8}\right]$-GnRH-I, which detects mammalian GnRH in addition to other vertebrate GnRH-I decapeptides (Quanbeck et al., 1997). A polyclonal sheep antibody, BDS 037 (a gift from Dr. A. Caraty, INRA, Nouzilly, France), raised against mammalian GnRH-I, which detects C-terminal epitopes of GnRH-I
(Caraty et al., 1995), was used for the dual-labeling immuofluorescence study. Adsorption control experiments were undertaken by incubating the respective GnRH antibody with GnRH-I ${ }^{1-10}$ peptide (Sigma) at a concentration of $5 \mu \mathrm{g} / \mathrm{ml}$ overnight at $4^{\circ} \mathrm{C}$ before use on brain sections.

Peroxidase-based immunostaining in adult mice. Adult (60- to 90-d-old) transgenic GnRH-LacZ (GNZ) and wild-type $(\mathrm{CBA} \times \mathrm{C} 57 / \mathrm{B} 16)$ mice were administered an overdose of tribromoethanol (Avertin; $0.2 \mathrm{ml} / 20$ gm, i.p.) and perfused directly through the left ventricle of the heart with $15-20 \mathrm{ml}$ of $4 \%$ paraformaldehyde in PBS, $\mathrm{pH}$ 7.4. Brains were removed and post-fixed for $1-2 \mathrm{hr}$ at room temperature before being placed in a $30 \%$ sucrose, Tris-buffered saline (TBS) solution at $4^{\circ} \mathrm{C}$. The following day, 30- $\mu \mathrm{m}$-thick coronal sections were cut into four sets of sections through the rostral forebrain, including the preoptic area and hypothalamus, using a freezing microtome. Free-floating immunocytochemistry was then undertaken by placing sections in a $1 \% \mathrm{H}_{2} \mathrm{O}_{2}, 40 \%$ methanol, TBS solution for 5 min followed by three washes in TBS. Sections were then incubated in one of the polyclonal rabbit primary antibodies ( $\beta \mathrm{gal}$, 1:8000; LR1, 1:20,000; SW1, 1:5000; and GF6, 1:8000) for $40-64 \mathrm{hr}$ at $4^{\circ} \mathrm{C}$ followed by TBS washing at room temperature and incubation in biotinylated goat anti-rabbit Igs (1:200; Vector Laboratories, Peterborough, UK) for $90 \mathrm{~min}$. Sections were then washed and placed in the Vector Elite avidin-peroxidase substrate $(1: 100)$ for a further $90 \mathrm{~min}$ before reacting with the nickel-diaminobenzidene tetrahydrochloride chromagen using glucose oxidase. The cytoarchitecture of selected coronal brain sections was determined by counterstaining with hematoxylin and eosin. All Igs were dissolved in TBS containing $0.3 \%$ Triton-X-100 and $0.3 \%$ bovine serum albumin, and primary antibody solutions also contained $2 \%$ normal goat serum. Controls consisted of the omission of one of the primary antibodies from the immunostaining protocol and the use of GnRH antibodies preadsorbed with GnRH peptide.

Dual-labeling immuofluorescence in adult mice. A set of coronal sections from adult mice were processed for dual $\beta$ gal-GnRH fluorescence by incubation in an antibody mixture comprising the polyclonal rabbit $\beta$ gal (1:4000) and polyclonal sheep GnRH-I (1:1000) Igs for $40 \mathrm{hr}$ at $4^{\circ} \mathrm{C}$. After washing in TBS at room temperature, the sections were placed in FITC donkey anti-rabbit (1:50; Jackson ImmunoResearch, West Grove, PA) and biotinylated horse anti-goat (1:200; Vector) Igs for $90 \mathrm{~min}$ at room temperature. After washing, sections were placed in Texas Redavidin $(2.6 \mu \mathrm{l} / \mathrm{ml}$; Vector $)$ for a further $90 \mathrm{~min}$ at room temperature and then mounted onto slides and coverslipped with Vectashield (Vector). Controls consisted of the omission of one of the primary antibodies from the immunostaining protocol. Sections were viewed under a Leica (Nussloch, Germany) DM-RB fluorescent microscope, and individual cells were examined at 40 or $100 \times$ objective magnification where switching between Texas Red (TX; Leica) and FITC (I3; Leica) filter sets determined whether cells were double-labeled. For each mouse, three or four sections containing the medial septum (see Fig. $2 B$ ) and three or four sections containing the rostral preoptic area (see Fig. $2 C$ ) were selected, and the number of GnRH-only and dual GnRH- $\beta$ gal-immunoreactive cells was counted in each animal. These counts provided an average value for each animal, which were used to determine mean \pm SEM values for each cell population.

Peroxidase-based immunostaining in embryonic and neonatal mice. Transgenic GNZ, Pax-6 mutant small eye (Sey) and wild-type adult female mice were time-mated with stud males at the Babraham Institute, and pregnancy was determined by the presence of vaginal plugs (morning of plug detection $=$ gestational day 0.5 ). These females were killed by cervical dislocation to provide embryonic day (E) 11.5, 12.5, 13.5, 14.5, 16.5, and 18.5 fetuses. Embryos were dissected and decapitated, and their whole heads either snap-frozen on dry ice or immersed in the $4 \%$

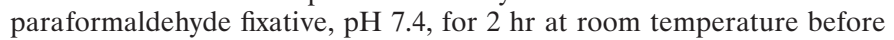
being placed in a $40 \%$ sucrose-TBS solution overnight at $4^{\circ} \mathrm{C}$. Snapfrozen embryonic brains were cut in the coronal plane on a cryostat at 15 $\mu \mathrm{m}$ thickness into four sets, whereas fixed brains were cut in either the coronal or sagittal plane at $30 \mu \mathrm{m}$ thickness into three sets on a cryostat and freeze-thawed onto gelatinized slides. Snap-frozen sections were kept at $-80^{\circ} \mathrm{C}$ until processed for immunocytochemistry, whereas sections from immersion-fixed brains were processed immediately after sectioning.

Brain sections from both protocols were brought to room temperature, immersed in $4 \%$ paraformaldehyde fixative for $30 \mathrm{~min}$, washed in TBS, placed in $1 \% \mathrm{H}_{2} \mathrm{O}_{2}, 40 \%$ methanol, and TBS for $5 \mathrm{~min}$, and washed again in TBS, and then 150-200 $\mu \mathrm{l}$ of primary antibody ( $\beta \mathrm{gal}, 1: 2000$; LR1, 1:4000; SW1, 1:3000; and GF6, 1:5000) in the Triton-X-BSA-TBS buffer with $2 \%$ normal goat serum added was placed on each slide so that all 
brain sections were covered. Slides were maintained in humidified chambers at $4^{\circ} \mathrm{C}$ for $72 \mathrm{hr}$, with an additional $50 \mu \mathrm{l}$ of respective antibody applied to each section each day. Slides were then washed several times in TBS before placing 150-200 $\mu \mathrm{l}$ of 1:200 biotinylated goat anti-rabbit Igs (Vector) on each slide for $90 \mathrm{~min}$ at room temperature. Slides were washed, and 150-200 $\mu \mathrm{l}$ of 1:100 Vector Elite reagent was placed on each slide for a further $90 \mathrm{~min}$. Slides were washed again in TBS and finally reacted with the nickel-diaminobenzidene tetrahydrochloride chromagen using glucose oxidase. Control experiments consisted of the incubation of slides in buffer missing a primary antibody and the use of adsorbed primary antibodies. Mice were also examined at postnatal $(\mathrm{P})$ days 3 and 4 and at day 16 . In the case of the P3/4 mice, neonates were decapitated, and their whole heads were immersed in the fixative solution and processed as above for the immersion-fixed embryonic brains. The P16 mice were treated in the same manner as the adults described above.

Dual X-gal-immunocytochemistry in embryonic mice. Homozygous GNZ 3252 E16.5 $(n=2)$ and E17.5 $(n=2)$ embryos were immersion fixed and cut in the coronal plane as described above. Slides were then placed in a X-gal solution $\left[2 \mathrm{~mm} \mathrm{MgCl}_{2}, 4 \mathrm{~mm} \mathrm{~K}_{3} \mathrm{Fe}(\mathrm{CN})_{6}, 4 \mathrm{~mm}\right.$ $\mathrm{K}_{4} \mathrm{Fe}(\mathrm{CN})_{6}$, and $4 \mathrm{mg} / \mathrm{ml}$ 5-bromo-4-chloro-3-indoyl- $\beta$-D-galactosidase in TBS] overnight at room temperature to reveal transgene-expressing cells in the brain. Sections were rinsed several times in TBS and processed for GF6 immunostaining exactly as described above. Slides were mounted with glycerin and viewed on a Leica DM RB microscope.

\section{In situ hybridization for $\beta$-galactosidase $m R N A$ in adult mice}

Adult male and female GNZ mice were killed by cervical dislocation, and their brains were rapidly removed and frozen on dry ice. Brains were stored at $-80^{\circ} \mathrm{C}$ until being cut on a cryostat in the coronal plane at 15 $\mu \mathrm{m}$ thickness through the septum and rostral hypothalamus and thawmounted onto gelatinized slides. Cut sections were stored at $-80^{\circ} \mathrm{C}$ until processed for in situ hybridization using the same procedure as that reported previously (Herbison and Fenelon, 1995). In this case, 40- and 45-mer oligonucleotides complimentary to nucleotides $1256-1295$ and 2822-2866 of $\beta$ gal cDNA, respectively, were synthesized and labeled with ${ }^{35} \mathrm{~S}$ to a specific activity of $10^{9} \mathrm{cpm} / \mu \mathrm{g}$. Slides were then hybridized with each probe individually or both. After hybridization, sections were coated with emulsion and left to develop for 8-10 weeks (dual probes) or 12 weeks (single probes) before being lightly counterstained with methylene blue and coverslipped with DPX. Competition experiments were undertaken by hybridizing slides with both probes but in the presence of a 50 -fold excess of unlabeled oligonucleotides.

Analysis of relative mRNA expression was undertaken using an image analyzer (Seescan, Cambridge, UK), which enabled the number of silver grains clustered over individual cells to be determined (Herbison and Fenelon, 1995). To determine the relative $\beta$ gal mRNA expression in the lateral septum and the GnRH neurons, the 20 highest expressing lateral septal cells found within two coronal brain sections were analyzed and compared with silver grain counts from 10-15 medial septal and 20 preoptic area GnRH neurons in each of the male and female mice. Silver grain counts from individual cells were combined to provide an average for each mouse, and these values were used to provide mean \pm SEM data. Statistical analysis was undertaken using the nonparametric MannWhitney $U$ test.

\section{In situ hybridization for GnRH-I-associated peptide $m R N A$ in embryonic mice}

To ensure that the GnRH expressed in the new populations was in fact derived from the GnRH-I gene, fresh-frozen sections from E14.5 embryonic wild-type mice were obtained as described above. In situ hybridization using a 48 mer oligonucleotide complementary to sequences encoding the last 16 amino acids of GnRH-I exon 3 (nucleotides 3095-3143), which are responsible for GnRH-associated peptide-I (GAP; Mason et al., 1986) was undertaken using the method described above for adult brain sections. Whereas relatively small differences exist in the sequences encoding the GnRH-I and GnRH-II decapeptides, the GAP sequence of GnRH-I and GnRH-II is highly divergent (White et al., 1998). After hybridization with a ${ }^{35} \mathrm{~S}$-labeled probe of specific activity of $10^{9} \mathrm{cpm} / \mu \mathrm{g}$, sections were coated with emulsion and left to develop for 7-10 d before being lightly counterstained with methylene blue and coverslipped with DPX. Competition experiments were undertaken by hybridizing slides with the GAP probe but in the presence of a 50-fold excess of unlabeled oligonucleotide.

\section{RESULTS}

Six transgenic founder mice (four male and two female) were derived, and three mice (male 3210, female 3235, and female 3252) were found to have offspring expressing the transgene. Blot analysis indicated that the 3252 line was likely to result from a single copy of the transgene, the 3235 line from a dual copy, and the 3210 from multiple $\sim 10$ copy insertion. Mice from the three lines appeared normal in all respects and exhibited normal levels of fertility. The 3252 line was bred to homozygosity, whereas transgene expression in the 3235 line was found to decline with generation number and the line culled. Results from offspring of the 3235 founder are included in the adult $\beta$ gal expression section.

\section{Transgene expression in adult mice}

\section{$\beta$-Gal immunocytochemistry}

The three lines of GNZ mice exhibited identical patterns of transgene expression. This consisted of cells displaying two different patterns of $\beta$ gal immunoreactivity; the most obvious population was a continuum of mostly bipolar-type immunoreactive neurons (Fig. 1A,B), which began in the medial septum and passed ventrally through the midline regions of the rostral preoptic area to reach the base of the lateral hypothalamus (Figs. $1-3)$. The second pattern of $\beta$ gal immunostaining consisted of a very light cytoplasmic staining coupled with the presence of an intensely staining intracytoplasmic "donut-like" organelle (Fig. $1 D, E$ ) commonly seen in neuronal LacZ transgenics (Friedrich et al., 1993). Cells exhibiting this pattern of immunoreactivity were found throughout the rostrocaudal length of the lateral septum, including its septohippocampal, dorsal, intermediate, and septofimbral nuclear divisions (Fig. $2 A-C$ ). Transgene-expressing cells in the intermediate division extended down its ventrolateral projections on either side of the diagonal band of Broca (Franklin and Paxinos, 1997; Fig. 2B,C). A few $\beta$ gal-immunoreactive cells were also detected laterally in the region of the olfactory tubercle (Fig. $2 B-D$ ). The second major population of cells expressing this "donut" pattern of $\beta$ gal immunoreactivity was found in, and adjacent to, the ventral-most part of the posterior division of the bed nucleus of the stria terminalis (pBNST; Fig. 2D). An identical pattern of transgene expression was observed using the chromogenic substrate Xgal to detect $\beta$-galactosidase (results not shown).

No differences were detected between males and females in any of the three lines, and breeding the 3252 line to homozygosity had no effect on the distribution or apparent intensity of $\beta$ gal immunoreactivity. In control experiments, in which the $\beta$ gal antibody was omitted from the procedure, no staining was evident in the sections. Equally, when $\beta$ gal immunostaining was undertaken on nontransgenic littermates, no staining resulted.

\section{Dual-labeling immunocytochemistry}

The relationship of $\beta$ gal immunoreactivity to GnRH neurons was determined by staining adjacent sections for $\beta$ gal and GnRH and also undertaking dual-labeling immuofluorescence for $\beta$ gal and GnRH. The staining of adjacent sections from both male and female GNZ mice revealed an identical pattern of cytoplasmic $\mathrm{GnRH}$ and $\beta \mathrm{gal}$ immunoreactivity within the medial septum and hypothalamus (Fig. $3 A, B$ ). $\beta$ Gal staining was not evident in the axons of neurons. Although GnRH-immunoreactive fibers and the very occasional bipolar cell body were detected in the lateral septum and BNST, we could find no evidence for cytoplasmic GnRH immunoreactivity within the distribution of the transgenic cells of the lateral septum and pBNST. The distribution of GnRH 

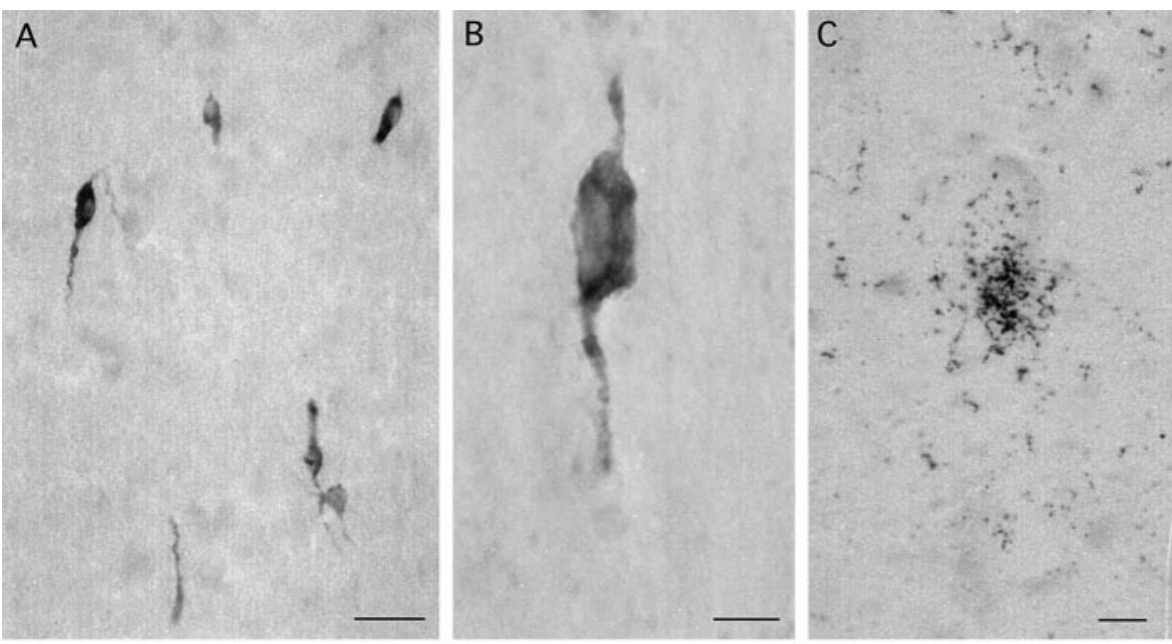

Figure 1. $\beta$ Gal immunoreactivity $(A, B, D, E)$ and mRNA expression $(C, F)$ in the rostral preoptic area $(A-C)$ and lateral septum $(D-F)$ of adult female GNZ mice. Note that $\beta$ gal immunoreactivity is present throughout the cytoplasm of GnRH neurons $(A, B)$ but located principally within circular donut-like structures $(E$, arrow $)$ in the cytoplasm of lateral septal cells $(D, E)$. Silver grain density after $\beta$ gal in situ hybridization is substantially greater in GnRH neurons $(C)$ compared with lateral septal cells $(F)$. Scale bars: $A, D$, $50 \mu \mathrm{m} ; B, C, E, F, 5 \mu \mathrm{m}$.
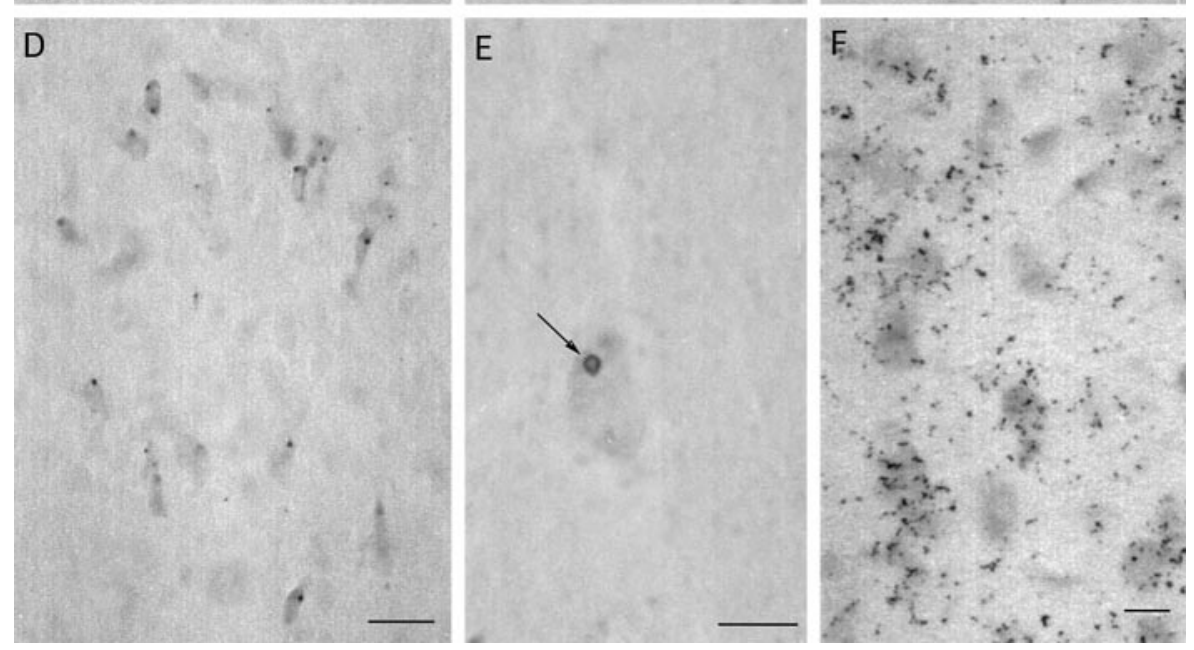

immunoreactivity observed was in complete agreement with previous studies in the mouse (Jennes and Stumpf, 1986; SchwanzelFukuda et al., 1987).

Dual-labeling immunofluorescence was undertaken on brain sections from four adult heterozygous 3210 males and five adult homozygous 3252 male mice. The pattern of immunofluorescence for $\beta$ gal and GnRH was identical to that observed with immunoperoxidase detection, and the great majority of GnRH neurons (red fluorescence; Fig. 3C) were found to contain green $\beta \mathrm{gal}$ immunofluorescence (Fig. 3D). Cell counts revealed that $85 \pm$ $3 \%$ of medial septal and $86 \pm 3 \%$ of rostral preoptic GnRHimmunoreactive neurons were also immunoreactive for $\beta$ gal in 3210 mice and that $81 \pm 4 \%$ of medial septal and $87 \pm 3 \%$ of rostral preoptic GnRH-immunoreactive neurons were positive for $\beta \mathrm{gal}$ in 3252 mice. In total, $85 \pm 3 \%$ (3210) and $86 \pm 3 \%$ (3252) of all GnRH neurons were found to express $\beta$ gal immunoreactivity. No GnRH immunoreactivity was detected in $\beta$ gal immunofluorescent cells of the lateral septum or pBNST. Omission of either the $\beta \mathrm{gal}$ or $\mathrm{GnRH}$ antibody resulted in an absence of green or red immunofluorescence, respectively, and dual labeling immunostaining on nontransgenic 3210 littermates resulted in only red immuofluorescence.

\section{$\beta$-Gal mRNA in situ hybridization}

Coronal brain sections of male $(n=5)$ and female $(n=5)$ adult homozygous 3252 mice underwent $\beta$ gal in situ hybridization and analysis in parallel. Sections hybridized with either of the single oligonucleotides or the two probes together as a mixture displayed a distribution of silver grain clusters identical to that of the $\beta$ gal immunostaining. However, the numbers of silver grains clustered over individual septal cells (Fig. $1 F$ ) were much lower than those observed over the midline-positioned cells of the medial septum and rostral preoptic (Fig. 1C). The distinct GnRH distribution pattern of the highly expressing cells in the rostral preoptic area and absence of non-GnRH transgenic cells in this area (Figs. $2 C, 3$ ) make it reasonable to assume that $\beta$ gal mRNAexpressing cells in the rostral preoptic area represent GnRH neurons.

The analysis of sections from male and female mice hybridized with the mixture of two $\beta$ gal oligonucleotides revealed that cellular $\beta$ gal mRNA expression was at least threefold greater in rostral preoptic GnRH neurons compared with cells located in the intermediate division of the lateral septum (males, lateral septum $65 \pm 5$ silver grains per cell vs $186 \pm 8$ in preoptic GnRH neurons; females, lateral septum $71 \pm 6$ silver grains per cell vs $238 \pm 16$ in preoptic GnRH neurons). A significant sex difference in cellular silver grain counts was evident for rostral preoptic area GnRH neurons ( $p=0.03$, Mann-Whitney $U$ test) but not lateral septal cells. Because the hybridization signal was relatively weak in the lateral septum (Fig. $1 F$ ), only the most highly expressing lateral septal cells were selected and, as such, this is likely to underestimate the difference in $\beta$ gal mRNA levels between the two populations. Sections hybridized in the presence of excess 


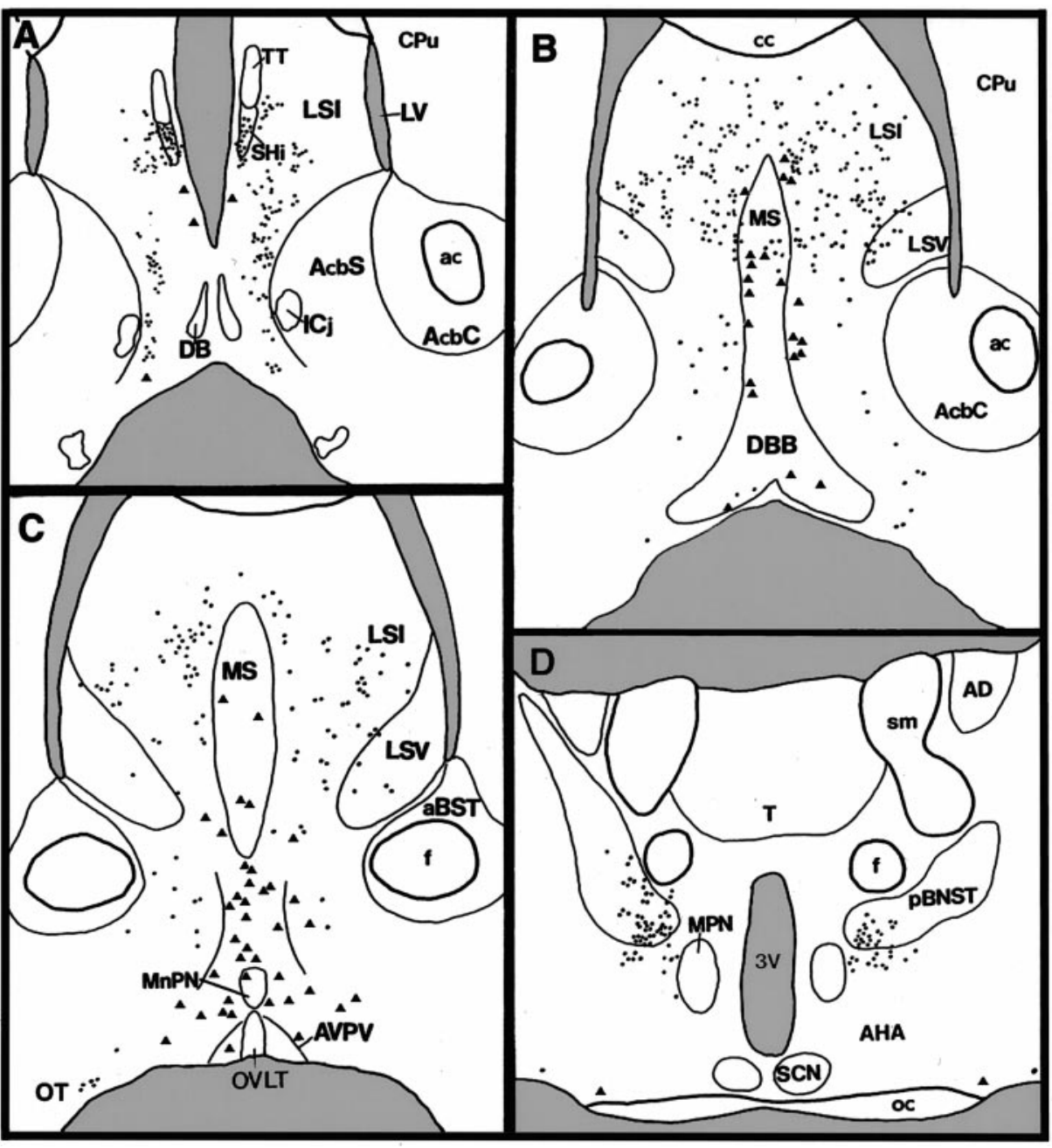

Figure 2. Camera lucida diagram of transgene expression in rostral $(A)$ to caudal $(D)$ coronal sections of a female GNZ mouse. Triangles represent $\beta$ gal-immunoreactive cells with intense cytoplasmic staining ( $\mathrm{GnRH}$ neurons), whereas dots represent cells exhibiting a light $\beta$ galimmunoreactive soma with distinct donuts (see Fig. 1E). aBST, Anterior bed nucleus of the stria terminalis; $a c$, anterior commissure; $A H A$, anterior hypothalamic area; $A c b C$, accumbens nucleus core; $A c b S$, accumbens nucleus shell; $A D$, anterodorsal thalamic nucleus; $A V P V$, anteroventral periventricular nucleus; $c c$, corpus callosum; $C p u$, caudate-putamen; $D B, D B B$, diagonal band of Broca; $f$, fornix; $I c j$, islands of Calleja; $L V$, lateral ventricle; $L S I$, intermediate division of the lateral septum; $L S V$, ventral division of the lateral septum; $M n P N$, median preoptic nucleus; $M P N$, medial preoptic nucleus; $M S$, medial septum; oc, optic chiasm; OT, olfactory tubercle; OVLT, organum vasculosum of the lamina terminalis; $p B N S T$, principal encapsulated division of bed nucleus of the stria terminalis; $S C N$, suprachiasmatic nucleus; $\mathrm{SHi}$, septohippocampal nucleus; $T$, thalamus; $T T$, tenia tecta; $s m$, stria medularis; $3 V$, third ventricle. unlabeled oligonucleotides displayed no silver grain clusters, and, equally, no signal was detected in coronal brain sections from nontransgenic mice.

\section{Transgene expression in embryonic and neonatal GNZ mice}

The analysis of transgene expression by $\beta$ gal immunocytochemistry in fresh-frozen and immersion-fixed embryonic brains revealed the presence of $\beta$ gal-immunoreactive cells in the classical distribution of the migrating GnRH neurons, as well as the lateral septum, pBNST, and, additionally, the developing tectum.

\section{Transgene expression in the nose}

Brains from heterozygous 3210 mice were analyzed at E11.5, 12.5, 13.5 , and 15.5 ( $n=3-5$ at each stage), and brains from homozygous 3252 mice were assessed at E11.5, 12.5, 13.5, 14.5, 16.5, and 18.5 ( $n=3-5$ at each stage) using $\beta$ gal and GnRH immunocytochemistry. In both lines of mice, $\beta$ gal-immunoreactive cells were detected in the olfactory placode-derived medial olfactory pit and vomeronasal organ and in clusters or cords of cells passing through the nasal septum to converge on a localized point at the base of the telencephalic hemispheres (Fig. 4A). Cells located in the medial olfactory pit were small and ovoid in shape with few stained processes (Fig. 4B), whereas immunoreactive cells clustered in the cords of cells within the nasal septum were elongated with unipolar or bipolar process (Fig. 4C). An analysis of the numbers of $\beta$ gal- and GnRH-immunoreactive cells detected in the nasal septum as a whole was undertaken in a series of snap-frozen immunostained E12.5-18.5 embryonic 3252 brains. This revealed an identical number of $\beta$ gal and GnRH cells in the nasal septum at each embryonic stage and, as reported previously for GnRH (Schwanzel-Fukuda and Pfaff, 1989; Wray et al., 1989), a decline in cells numbers during development (Fig. 5).

\section{Transgene expression in the brain}

Cells immunoreactive for $\beta$ gal were detected in the developing septum from E11.5 onward (Fig. 4A,D). Between E11.5 and 13.5, they were found to be small in diameter $(6.1 \pm 0.2 \mu \mathrm{m}$; range, $5.8-7.8 \mu \mathrm{m})$ and usually displayed an ovoid ring of cytoplasmic immunoreactivity without any stained processes. After E13.5 a second type of cell was encountered in the septum, which was larger in diameter, often exhibiting a clear unipolar or bipolar morphology, and more intensely stained (Fig. 4D,E). Although the bipolar-type cell was restricted to the more medial and frontal aspects of the septum (Fig. 4D), the small cells remained localized within the lateral septum. Coronal sections in E14.5 and neonatal (P3/4 and P16) mice confirmed that the small ovoid cells were restricted to the lateral septum. The staining of consecutive immersion-fixed parasagittal sections for GnRH and $\beta$ gal in E13.5-18.5 embryos revealed a similar distribution of immunore- 

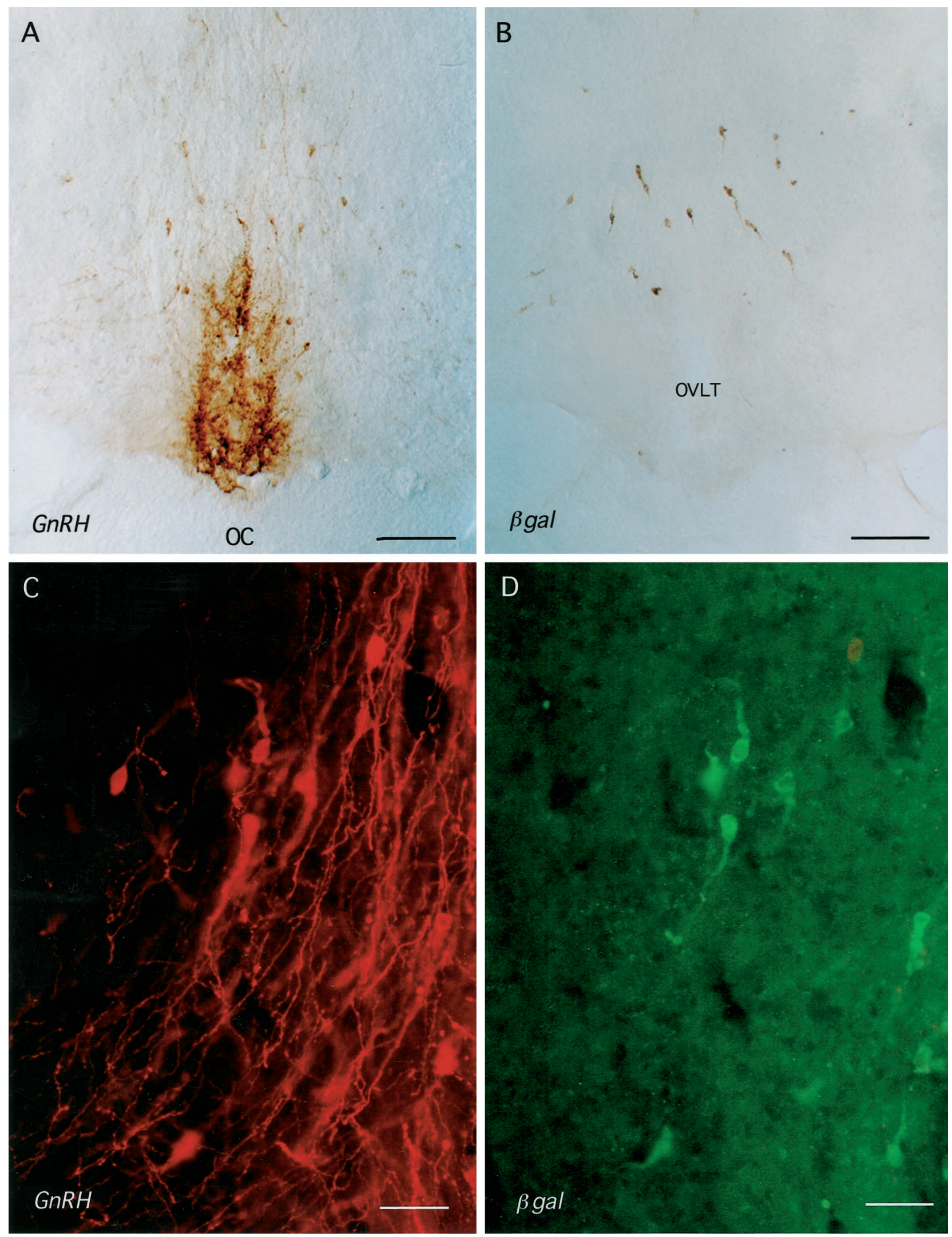

Figure 3. Coronal rostral preoptic area sections of male 3252 mice immunostained for $\mathrm{GnRH}(A, C)$ and $\beta$ gal $(B, D)$. $A, B$, Immunoperoxidase staining on consecutive coronal sections for $\operatorname{GnRH}(A)$ and $\beta$ gal $(B)$ shows a similar distribution of cell body staining. $O C$, Optic chiasm; $O V L T$, organum vasculosum of the lamina terminalis. Scale bar, $250 \mu \mathrm{m}$. $C, D$, Dual-labeling immuofluorescence for GnRH $(C$, red $)$ and $\beta$ gal $(D$, green). Note that the GnRH neurons in view express different levels of $\beta$ gal immuofluorescence and that, as seen in $B$, GnRH axons rarely express $\beta$ gal immunoreactivity. Scale bar, $40 \mu \mathrm{m}$. 

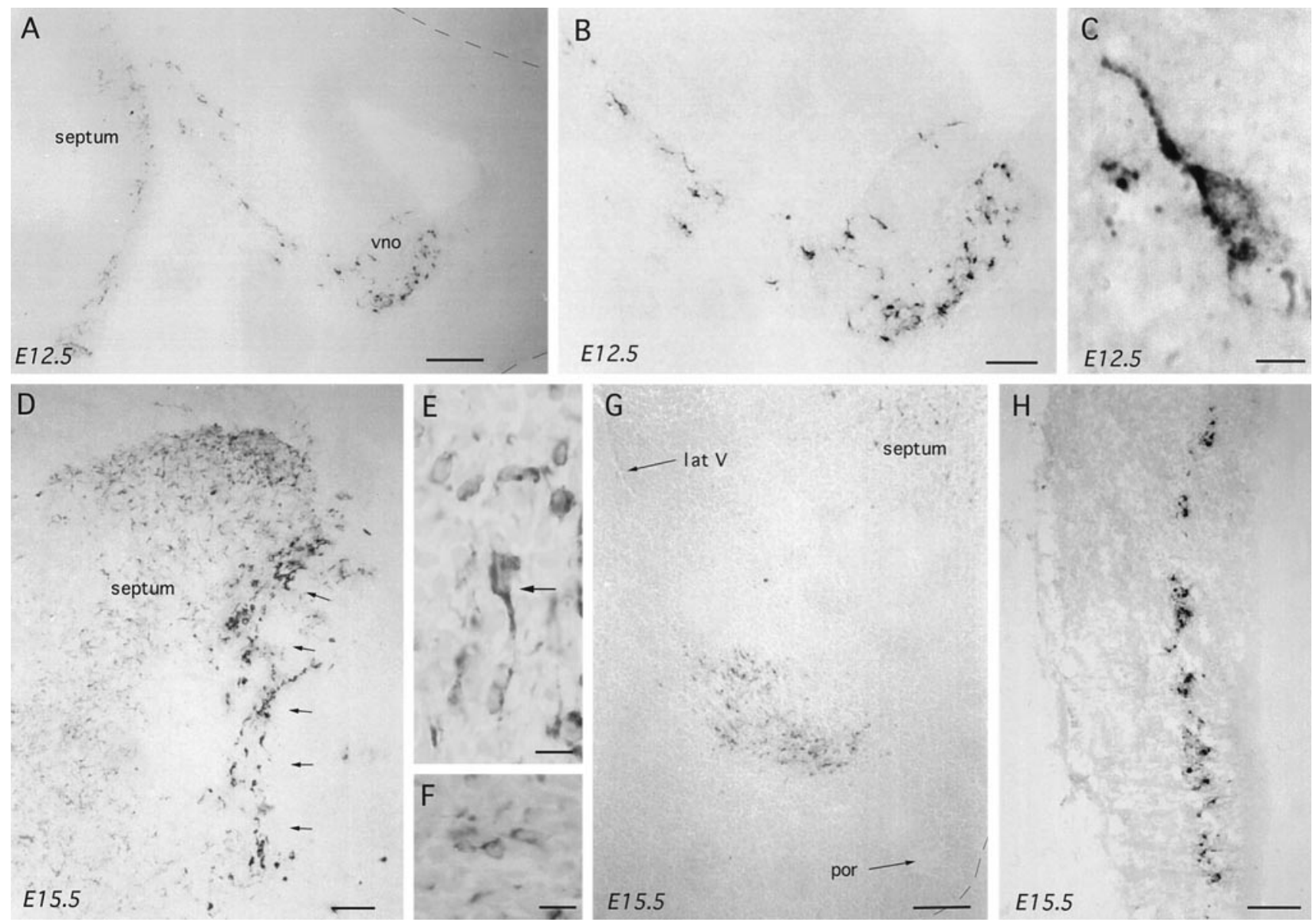

Figure 4. $\beta \mathrm{Gal}$ immunoreactivity in parasagittal sections of embryonic GNZ 3252 mice. In all photomicrographs the nose is to the right. $A-C$, Increasingly high-power views of $\beta$ gal immunoreactivity in the nose and developing septum of an E12.5 embryo. Note the large numbers of immunoreactive cells within the vomeronasal organ ( $v$ no $)$ with tracks of cells passing back to the developing forebrain where $\beta$ gal-immunoreactive cells are already present. A high-power view of a cell in the nasal septum is shown in $C$. Scale bars: $A, 100 \mu \mathrm{m} ; B, 50 \mu \mathrm{m} ; C, 5 \mu \mathrm{m}$. $D, E$, Low- and high-power views of $\beta$ gal-immunoreactive cells within the developing septum of an E15.5 mouse. Two types of immunoreactive cells are present; one with strong, often bipolar, cytoplasmic staining (E, arrow), which were found in the most rostral part of the septum (D, arrows), and another displaying fainter immunoreactivity in smaller-diameter cells often without processes $(E)$, which were scattered throughout the septum $(D)$. Scale bars: $D$, $100 \mu \mathrm{m} ; E$, 10 $\mu \mathrm{m} . F, G$, High- and low-power views of $\beta$ gal-immunoreactive cells within the developing preoptic area and bed nucleus of the stria terminalis of an E15.5 mouse. Multiple small and faintly immunoreactive cells $(F)$ are observed clustered between the preoptic recess (por) and the lateral ventricle (lat $V$ ) separate from the septal population $(G)$. Scale bars: $F, 10 \mu \mathrm{m} ; G, 100 \mu \mathrm{m} . H, \beta$ Gal-immunoreactive cells are also present in a distinct band within the inner half of the developing tectum. Scale bar, $120 \mu \mathrm{m}$.

activity with numerous small ovoid cells also being identified with the LR1 antibody in the lateral septum (Fig. 6A).

Cells immunoreactive for $\beta$ gal were also detected between the septum and the preoptic recess streaming up toward the lateral ventricle (Fig. 4G). These cells, which were similar in morphology to those identified in the lateral septum (Fig. $4 F$ ), were first detected on E14.5 and, in coronal E16.5 sections, observed to lie within the ventral pBNST and preoptic area.

Dual labeling X-gal-GnRH (GF6) immunostaining in coronal sections of E16.5-17.5 embryos demonstrated co-expression of the transgene and GnRH immunoreactivity through the presence of blue X-gal reaction product in the great majority of brown GF6-immunoreactive cells. Dual-labeled cells were observed in the classical distribution of GnRH neurons as well as in the lateral septum and pBNST. A third population of transgene-expressing cells was observed in the inner half of the tectum (Fig. 4H). In this case, $\beta$ gal-immunoreactive cells were not detected until E15.5 but had disappeared by P3/4. Immunoreactive cells were found to display a regular ovoid morphology with few processes.

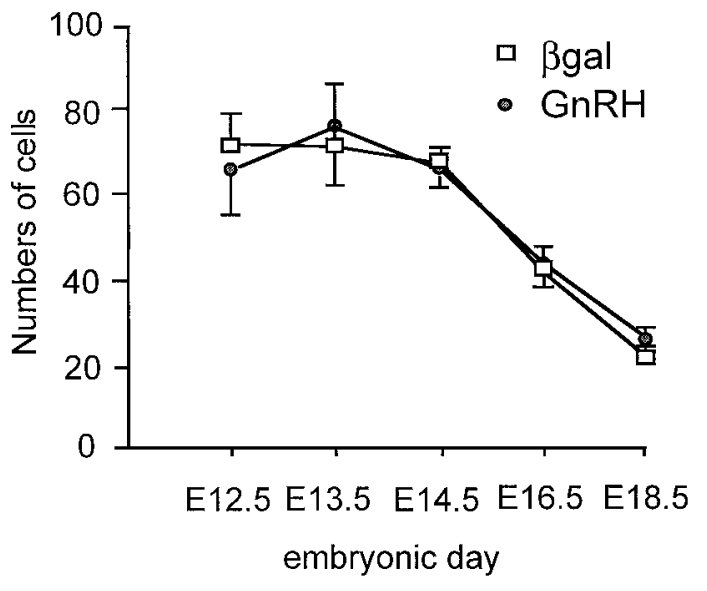

Figure 5. Mean \pm SEM numbers of GnRH- and $\beta$ gal-immunoreactive neurons detected in the three most midline parasagittal sections of the nasal septum of E12.5, 13.5, 14.5, 16.5, and 18.5 3252 GNZ mice $(n=4-5$ at each stage). 

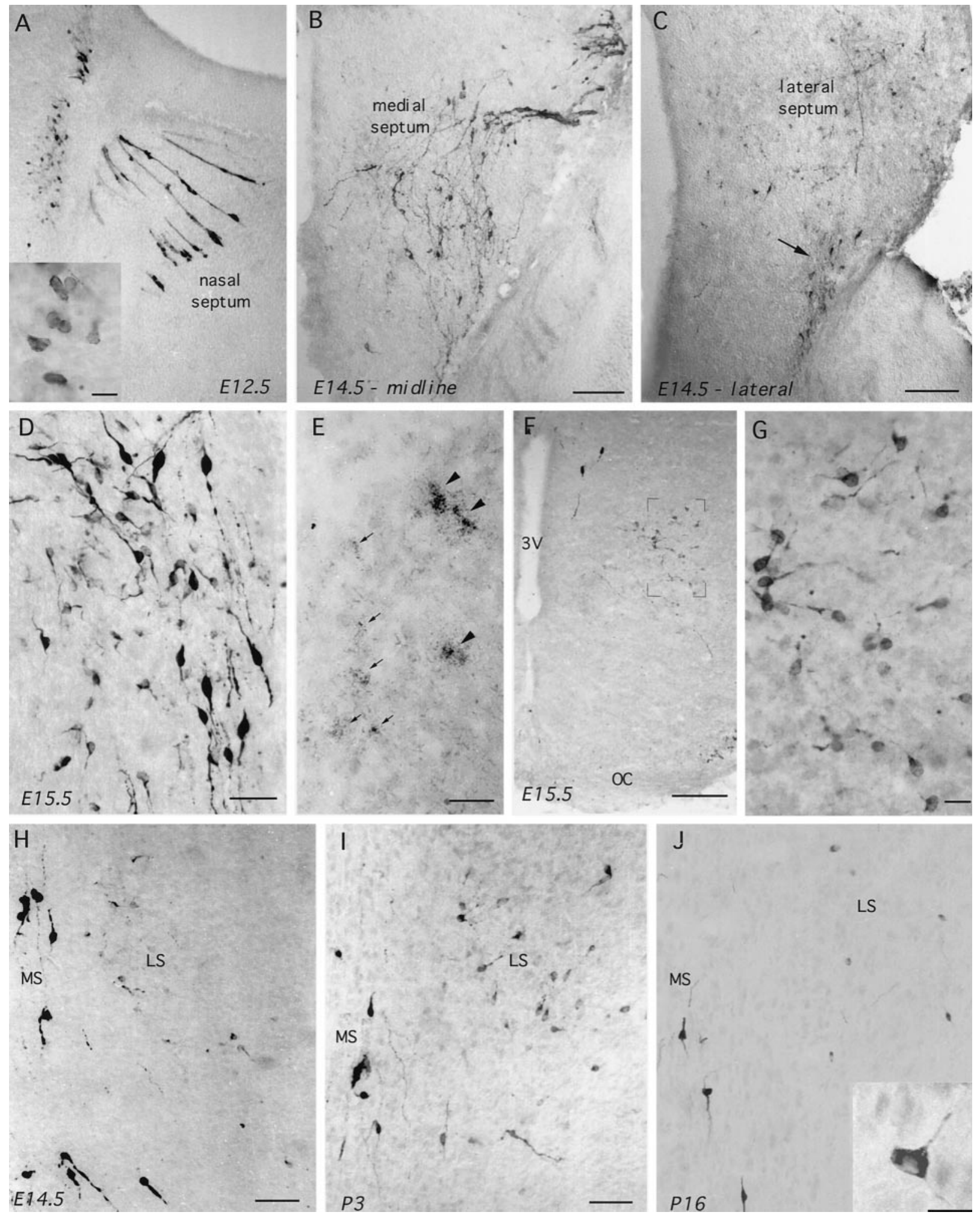

Figure 6. GnRH-I in parasagittal $(A-E$; nose is to the right) and coronal $(F-J)$ sections of wild-type embryonic and postnatal mice. $A$, GnRHimmunoreactive (LR1) cells in the nasal septum and developing telenchephalon of an E12.5 mouse. Note the typical appearance of GnRH neurons migrating through the nose in tracks and also the immunoreactive cells present along the rostral edge of the brain. Inset (scale bar, $10 \mu \mathrm{m}$ ), Typical ovoid morphology of these cells. $B, C$, GnRH immunoreactivity (GF6) in a midline parasagittal section $(B)$ and a section $300 \mu \mathrm{m}$ lateral to it $(C)$ of an E14.5 mouse. Note in $B$ the typical distribution of the migrating GnRH neurons as they enter the brain and pass down through the septum. In the more lateral section $(C)$, some of these bipolar migrating GnRH neurons can be seen leaving the septum (arrow), whereas a number of fainter and smaller immunoreactive neurons are evident scattered throughout the lateral septum. Scale bars, $200 \mu \mathrm{m}$. $D$, GnRH immunoreactivity (LR1) in the septum of an off-midline parasagittal section from an E15.5 mouse. Note the presence of intensely stained bipolar neurons alongside small round and multipolar-shaped cells. Scale bar, $40 \mu \mathrm{m}$. E, GAP-I mRNA in situ hybridization in septum of E15.5 mouse. Note the presence of both very high (arrowheads) and low (arrows) expressing cells. Scale bar, $15 \mu \mathrm{m} . F, G$, Coronal sections showing GnRH-immunoreactive (GF6) (figure legend continues) 
Staining consecutive parasagittal sections with the LR1 antibody revealed the same pattern of immunoreactivity.

In all cases, the staining of nontransgenic embryonic and postnatal mice resulted in an absence of $\beta$ gal immunostaining, and the adsorption of the LR1 antibody with GnRH peptide abolished staining.

\section{GnRH-I in wild-type mice}

Because work detailed above in the GNZ mice suggested that multiple GnRH-I-expressing cell populations existed, a series of studies was undertaken in nontransgenic $(\mathrm{CBA} \times \mathrm{C} 57 / \mathrm{B16}) \mathrm{em}-$ bryonic and neonatal (E11.5, E12.5, E14.5, E15.5, E19.5, P3/4, and P16; $n=3-5$ at each stage, except E19.5, $n=2$ ) and adult mice $(n=4$, each sex), which underwent the immersion-fixation (E11.5-P3/4) or perfusion-fixation (P16 and adult) immunocytochemistry procedure using three different GnRH-I antisera.

In addition to the classical pattern of GnRH-I immunoreactivity in the nasal septum and forebrain (Fig. 6A,B), all three antibodies detected a large number of relatively faintly stained, small-diameter $(6-8 \mu \mathrm{m})$, circular or ovoid-shaped cells within the lateral septum from E11.5 onward. At E11.5 and 12.5, immunoreactive cells were located within the rostral edge of the developing telencephalon (Fig. 6A), whereas in older embryos they were distributed throughout the lateral septum (Fig. 6B, $C, H-J$ ). Parasagittal sections cut through the boundary of the medial and lateral septum revealed the presence of both types of cell side by side in embryonic animals (Fig. 6D). In all cases, the immunoreactivity exhibited by the bipolar GnRH neurons of the medial septum and hypothalamus was much stronger than that observed in the small immunoreactive neurons of the lateral septum (Fig. $6 A-D)$. Counts of GF6-immunoreactive cell profiles in serial sagittal sections from three E14.5 mice revealed that $\sim 600$ smallsized, circular or ovoid-shaped GnRH cells existed within the lateral septum at this age (individual embryo estimates of 408, 618, and 711 cells). Fine immunoreactive cell processes were sometimes associated with these small cells, but it was not until after birth that their multipolar nature was readily apparent in all cells (Fig. 6J). The numbers of GnRH-immunoreactive cells in the lateral septum were reduced after birth and no longer detectable with the LR1 or SW1 antibody at P3/4 (Figs. 6H-J, 7). Thus, by P16 only a few GF6-immunoreactive cells were detectable in the lateral septum, where they were found alongside the classical $\mathrm{GnRH}$ neurons in the ventral projections of the intermediate division of the lateral septum (Fig. $6 J$ ). These cells could not be detected in adult mice of either sex.

A similar developmental sequence was found for $\mathrm{GnRH}$ in the pBNST, where a small number of faintly stained immunoreactive cells were first observed at E14.5, but thereafter, these cells were only detected with the GF6 antibody (Fig. 6F,G). These cells displayed a small ovoid-type of morphology, similar to those of the lateral septum, and many exhibited fine immunoreactive processes (Fig. 6G) . Counts of GF6-immunoreactive cell profiles in serial coronal sections from three E15.5 mice revealed that $\sim 200 \mathrm{GnRH}$-expressing cells formed the pBNST population at

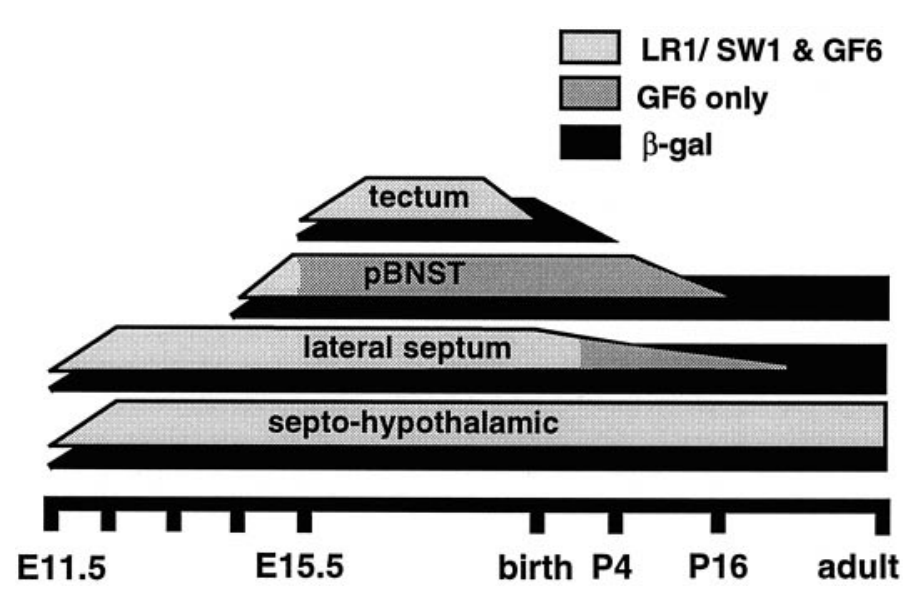

Figure 7. Schematic indicating the developmental profile of $\beta$ gal and GnRH immunoreactivity in the septohypothalamic, lateral septum, pBNST, and tectal cell populations of the wild-type and GNZ mouse. The gray shading indicates whether GnRH immunoreactivity was detected with all three GnRH antibodies (LR1, SW1, GF6; light gray) or GF6 alone (dark gray).

this age (individual embryo estimates of 174, 180, and 276 cells). Using the GF6 antibody, these cells persisted until P3/4 but were greatly reduced in number by $\mathrm{P} 16$ and absent in adults of either sex (Fig. 7).

A third pattern of GnRH staining was found in the tectum. Here, all three GnRH antibodies detected the same population of ovoid-shaped cells from E15.5 through E19.5. Thereafter, all three equally failed to detect any cells within the tectum of postnatal mice (Fig. 7). The mean diameter of immunoreactive cells at E16.5 was 7.3 $\mu \mathrm{m}$ (range, 5.8-9.6 $\mu \mathrm{m}$ ). In all cases, the immunostaining of sections with LR1, SW1, or GF6 antibody preadsorbed with GnRH-I peptide resulted in a complete absence of immunoreactivity. Furthermore, no staining was evident with any of the three antibodies in the midbrain of mice. Although GnRH-II has not, as yet, been detected in rodents, all other species show GnRH-II in this location (Muske, 1993; Sherwood et al., 1993; Lescheid et al., 1997; Tobet et al., 1997).

One set of E15.5 brains from five wild-type mice underwent in situ hybridization with the GAP-I probe. Dense clusters of silver grains (Fig. 6E) were found over cells extending from the nasal septum through to the preoptic area in a distribution identical to that observed previously (Wray et al., 1989) for the migrating GnRH neurons. In addition, a number of cells with a lot fewer silver grains per cluster were detected throughout the lateral septum (Fig. $6 E$ ), in the developing BNST, and also in the tectum with the same distribution as that found after GnRH-I immunostaining. Two control sections hybridized in the presence of excess unlabeled GAP-I probe displayed no silver grain clusters.

\section{GnRH immunoreactivity in Small eye (Sey) mice}

Because Sey mice fail to develop an olfactory placode (Thieler et al., 1978; Hogan et al., 1986; Hill et al., 1991), they represented a

$\leftarrow$

cells in the ventral pBNST of an E15.5 mouse. Note in $F$ the presence of two "normal" intensely stained bipolar cells near the third ventricle ( $3 \mathrm{~V}$ ) and the population of fainter cells magnified in $G$. OC, Optic chiasm. Scale bar: $F, 200 \mu \mathrm{m} ; G, 15 \mu \mathrm{m}$. $H-J$, Coronal views through the medial septum (MS) and lateral septum (LS) after GnRH immunocytochemistry (GF6) in E14.5 $(H)$, P3 $(I)$, and P16 $(J)$ mice. Note that the intensely staining bipolar neurons reside within the medial septum at all stages, whereas the number of more faintly staining, small-sized cells in the lateral septum become markedly less in number at P16. J, inset, Typical multipolar morphology of lateral septal GnRH neurons in postnatal mice. Scale bars: $H$, $I$, $80 \mu$ m; $J, 10 \mu \mathrm{m}$. 

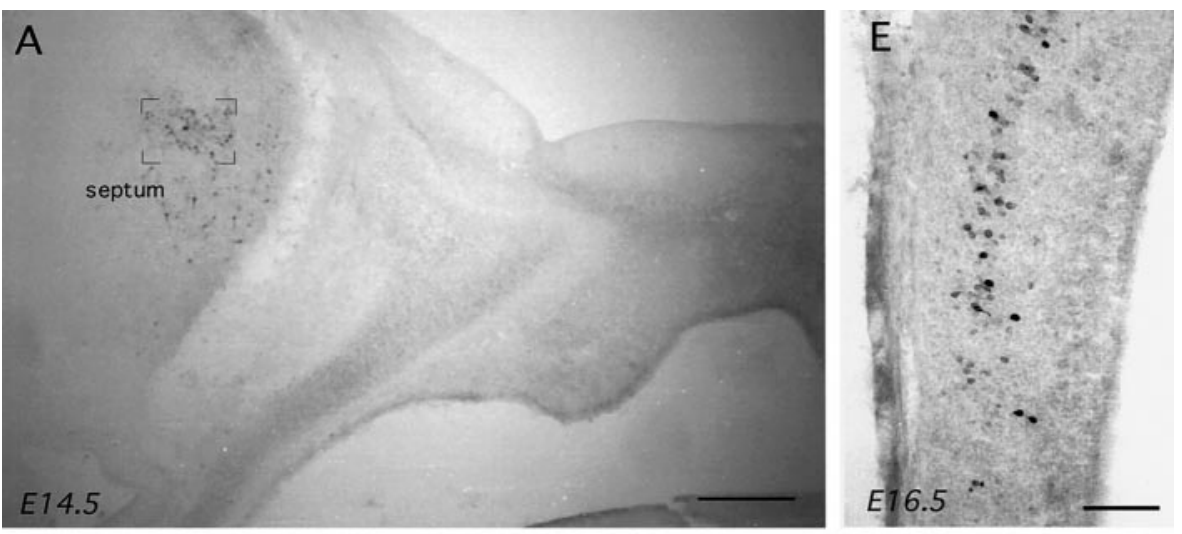

Figure 8. GnRH immunoreactivity in parasagittal sections (nose to the right) of the embryonic Sey mouse. $A, B$, Low- and high-power views of GnRH immunoreactivity (GF6) in an E14.5 Sey mouse. Note the complete absence of GnRH staining within the nose but presence, magnified in $B$, within the septum. Scale bars: $A, 250 \mu \mathrm{m} ; B$, $40 \mu \mathrm{m} . \quad C, D$, High-power views of $\mathrm{GnRH}-$ immunoreactive (LR1) cells in the septum. Scale bars, $10 \mu \mathrm{m}$. $E, F$, GnRH immunoreactivity $(E$, GF6; $F$, LR1) in the tectum of an E16.5 Sey mouse. Scale bars: $E, 140 \mu \mathrm{m} ; F, 10 \mu \mathrm{m}$.
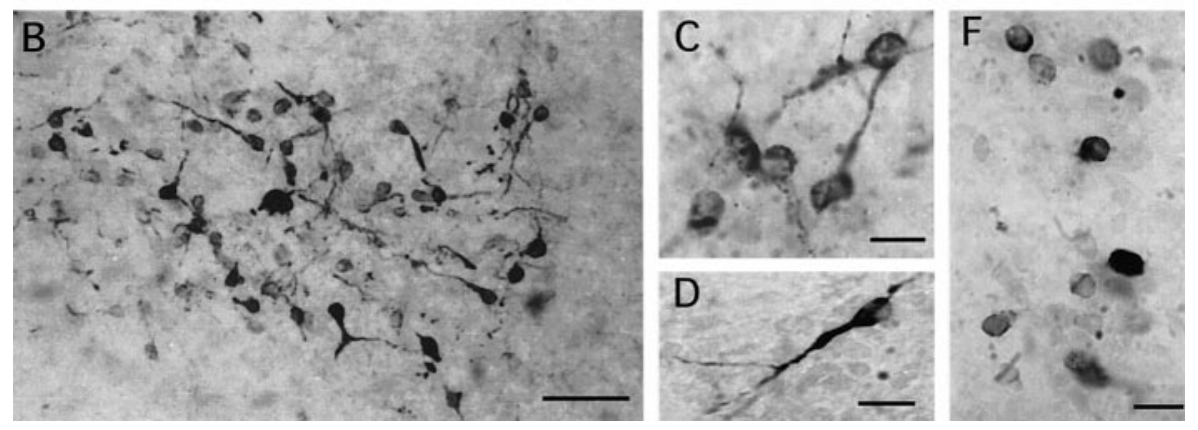

useful model for examining whether any of the new GnRH-I populations identified in these studies share a common embryological origin with the septohypothalamic GnRH-I neurons, which are born in the olfactory epithelium (Schwanzel-Fukuda and Pfaff, 1989; Wray et al., 1989). Immersion-fixed immunocytochemistry was undertaken on six E14.5-16.5 homozygous Sey embryos taken from four different litters, which were cut in coronal and parasagittal planes. Homozygous Sey mice were obtained by crossing heterozygous Sey mice and selecting embryos without any visual pigment. No GnRH immunoreactivity was detected in the nose of Sey mice with any of the three GnRH antibodies (Fig. 8A). However, LR1-, SW1-, and GF6immunostained cells were present in the lateral septum (Fig. $8 B-D$ ) and tectum (Fig. $8 E, F$ ) of Sey mice, whereas staining in the pBNST was only detected with the GF6 antibody. The distribution and morphology of immunoreactive cells in all three areas was identical to that observed in wild-type and GNZ mice (Fig. 8). In comparison with wild-type mice, the GnRH staining intensity in the lateral septum appeared to be stronger in Sey mice, and a few cells were detected that were small in size but exhibited a bipolar-type morphology (Fig. $8 D$ ). The removal of primary antibody or preadsorbtion of the LR1 antibody with GnRH resulted in an absence of immunoreactivity in Sey brains.

\section{DISCUSSION}

We report here that a $13.5 \mathrm{~kb}$ murine GnRH construct is sufficient to direct the correct temporal and spatial expression of the lacZ reporter to native $\mathrm{GnRH}$ neurons in three independent lines of GNZ transgenic mice. Using dual immuofluorescence we demonstrate that $\sim 85 \%$ of GnRH neurons in the medial septum and hypothalamus of the adult mouse express $\beta$ gal. In other transgenic lines derived using the same construct, but in which $\beta$ gal protein is directed toward the nucleus of the cell to enable dual-labeling peroxidase-based immunocytochemistry, $95-100 \%$ of the GnRH neurons are found to express $\beta$ gal (J. R. Pape, M. J. Skynner and A. E. Herbison, unpublished observations). Thus, it seems most likely that the $10-15 \%$ of GnRH neurons in GNZ mice without $\beta$ gal immunoreactivity are expressing $\beta$ gal at a level below our detection limit with immuofluorescence. It has been notoriously difficult to achieve cell-specific expression in the brain using neuropeptide gene promoter-driven reporters (Waschek, 1995). The almost perfect targeting of GnRH neurons reported here is in good agreement, however, with the functional study by Mason and colleagues (1986) in which the same $13.5 \mathrm{~kb}$ of GnRH sequence was used to restore reproductive fertility to the $\mathrm{GnRH}$ null hypogonadal mouse. Because this construct contains sufficient cis-acting regulatory elements with which to specify expression in GnRH-I neurons, the GNZ lines described here will provide a useful "baseline" for future in vivo promoter analysis and the targeting of the GnRH phenotype.

\section{"Ectopic" neural populations with promoter-driven transgenics}

The presence and extent of unexpected transgene-expressing populations observed in the brain of GNZ mice were somewhat surprising. Previous research using a similar GnRH construct (Mason et al., 1986) did not report extensive expression outside of the classic septohypothalamic GnRH neurons. Equally, transgenic mice carrying a human GnRH promoter driving the luciferase reporter were not described to exhibit substantial expression outside the hypothalamus (Wolfe et al., 1996). We show here, with quantitative $\beta \mathrm{gal}$ in situ hybridization, that the level of transgene mRNA expression in lateral septal cells is at least fourfold lower than that of septohypothalamic GnRH neurons. A preliminary report also suggests that relatively low levels of $\beta \mathrm{gal}$ expression exist in the lateral septum of transgenic mice bearing a $3 \mathrm{~kb}$ murine $\mathrm{GnRH}$ promoter-lacZ construct (Spergel et al., 1997). Thus, it seems likely that this reduced level of mRNA expression, employment of luciferase as a reporter, and/or use of the human GnRH promoter in the mouse are likely to underlie the failure to identify these newly identified $\mathrm{GnRH}$ populations in other transgenic lines. 
The presence of so-called ectopic populations of transgeneexpressing cells in the brain has been reported frequently in both neuronal and non-neuronal promoter-driven transgenic lines (Gunzburg et al., 1991; Rubenstein et al., 1992; Ang et al., 1993; Min et al., 1994; Waschek, 1995). The pattern of transgene expression in GNZ mice was found to be consistent within the three lines and, therefore, is unlikely to be a consequence of a transgene "position effect." In light of the necessity for neurons to maintain a diverse, yet cell-specific, pattern of gene regulation, the presence of previously unrecorded transgene expression in just three, apparently disparate neuronal cell populations was intriguing. Previous investigators had speculated that so-called ectopic transgene expression in the brain may reflect developmental patterns of gene regulation (Min et al., 1994; Waschek, 1995). We now demonstrate conclusively that this is indeed the case, because each of the three apparent ectopic populations is shown here to express authentic GnRH-I during development. This finding raises the likelihood that transgene expression described previously as ectopic in other pedigrees may actually represent activation of the transgene in developmentally relevant neuronal cell populations.

Our immunocytochemical studies clearly show that the endogenous GnRH-I gene is not expressed in the lateral septum and BNST of the adult despite the presence of transgene mRNA and protein in these populations throughout life. Thus, it seems most likely that cis- or trans-acting repressor elements not present in the transgene are brought into play in late development to suppress GnRH-I gene transcription in the lateral septum and BNST. This suggests that distinct groups of cells are programmed to activate the GnRH-I gene but that, as in other neuronal phenotypes (Goodman and Mandel, 1998), transcriptional repressors are important in restricting GnRH-I expression to just the septopreoptic GnRH neurons in the adult. The identity of the repressors maintaining the adult pattern of GnRH-I expression is unknown. However, we note that transgene and GnRH-I expression starts and stops in parallel within the developing tectum, suggesting that tectal cells use a unique repressor complex which is present within the $13.5 \mathrm{~kb}$ construct.

\section{Presence of multiple GnRH-expressing neurons in mammalian brain}

It is established in a wide range of species that GnRH-I and GnRH-II are expressed in distinct, spatially restricted regions within the brain; the GnRH-I population is distributed in a specific septohypothalamic distribution, whereas GnRH-II neurons are located within the midbrain (Muske, 1993; Sherwood et al., 1993; Lescheid et al., 1997). Taking insight from the distribution of transgene-expressing populations in GNZ mice, we now demonstrate the existence of four distinct populations of GnRH-I neurons in the normal mouse. One represents the neuroendocrine septohypothalamic GnRH neurons, whereas the other three are anatomically and developmentally distinct neuronal populations, which express GnRH-I in a transient manner during development. All three of the newly identified populations are synthesizing authentic GnRH-I rather then GnRH-II, because (1) they are detected by three different GnRH-I antibodies; (2) each population was found to express mRNA transcribed from GnRH-I exon III, a highly divergent region of the GnRH-I and GnRH-II genes (White et al., 1998); (3) the tectal population has been shown previously to be GnRH-I in nature (Wu et al., 1995); and (4) the cells were all targeted by $13.5 \mathrm{~kb}$ of GnRH-I sequence.

Although the identification of GnRH-I populations in the lat- eral septum and BNST is new, transient GnRH-I immunoreactivity had been detected previously in the tectum by $\mathrm{Wu}$ and colleagues (1995) and is in excellent agreement with the present findings. Furthermore, recent work in the primate indicates that these newly identified GnRH populations may not simply be a phenomenon of rodents. N-terminal GnRH immunoreactivity was recently revealed in neurons within a number of different brain regions, including the lateral septum, amygdala, claustrum, and globus pallidus of embryonic monkeys (Quanbeck et al., 1997). Indeed, the distribution and morphology of such cells within the developing lateral septum of the monkey are highly reminiscent of those reported here.

We also demonstrate that these new populations of $\mathrm{GnRH}$ neurons do not originate from the olfactory placode, the birth site of the septohypothalamic neurons (Schwanzel-Fukuda and Pfaff, 1989; Wray et al., 1989). The Sey phenotype arises from a point mutation in the Pax- 6 gene and results in mice with failed development of the eye and olfactory placodes (Thieler et al., 1978; Hogan et al., 1986; Hill et al., 1991). As found previously (Dellovade et al., 1998), none of the migrating septohypothalamic GnRH-I neurons was present in homozygous Sey mice. However, in striking contrast, we observed normal populations of GnRHI-immunoreactive cells in the lateral septum, BNST, and tectum of Sey mice. This indicates that these cells must have a nonplacodal origin and that, equally, their development is independent of Pax-6. Although studies in chicken have shown that GnRH-II, and possibly thalamic GnRH-I, neurons originate outside of the olfactory system (Norgren and Gao, 1994; Northcutt and Muske, 1994), the present work is the first to prove a nonplacodal origin of GnRH-I neurons in mammals.

The function of these newly identified $\mathrm{GnRH}$ populations is unknown. However, the identification of distinct brain regions that express GnRH-I, and one that continues to synthesize GnRH-I into the third postnatal week, suggests that this neuropeptide may have previously unsuspected roles in neural development. Our studies also indicate that a unique form of GnRH-I processing occurs within the lateral septal and BNST cell populations. Although immunoreactivity in these structures was detected initially with all three GnRH-I antibodies, both LR1 and SW1 immunoreactivity ceased at specific developmental time points only to leave the GF6 immunoreactivity before it too disappeared (Fig. 7). The septopreoptic GnRH neurons, which are able to fully process the pro-GnRH precursor by E14.5 (Livine et al., 1993), show equivalent GF6 immunoreactivity throughout embryonic and postnatal development. Because the GF6 antibody is directed against the $\mathrm{N}$-terminal region of GnRH-I (Quanbeck et al., 1997), it is possible that this pattern of staining represents cell-specific patterns of GnRH cleavage within late embryonic septal and BNST neurons.

In summary, we report that $13.5 \mathrm{~kb}$ of $\mathrm{GnRH}$ sequence is sufficient to direct transgene expression to the classical GnRH neurons throughout development. Cells expressing transgene were also detected in the lateral septum, pBNST, and tectum of GNZ mice, and subsequent immunocytochemical and in situ studies in wild-type mice have proven that these cells express authentic GnRH-I for differing periods during embryonic and postnatal development. Further investigations in Pax-6 mutant mice have shown that none of these newly identified populations of GnRH neurons originates from the olfactory placode. Together, these observations represent the identification of multiple GnRH neuronal populations of diverse embryological origin within the mammalian brain and indicate that so-called ectopic 
reporter expression in transgenic animals may reveal novel patterns of developmental gene expression within the brain.

\section{REFERENCES}

Ang H-L, Carter DA, Murphy D (1993) Neuron-specific expression and physiological regulation of bovine vasopressin transgenes in mice. EMBO J 12:2397-2409.

Caraty A, Antoine C, Delaleu B, Locatelli A, Bouchard P, Gautron J-P, Evans NP, Karsch FJ, Padmanabhan V (1995) Nature and bioactivity of gonadotropin-releasing hormone (GnRH) secreted during the GnRH surge. Endocrinology 136:3452-3460.

Dellovade TL, Pfaff DW, Schwanzel-Fukuda M (1998) The gonadotropin-releasing hormone system does not develop in small-eye (Sey) mouse phenotype. Dev Brain Res 107:233-240.

Franklin KBJ, Paxinos G (1997) The mouse brain in stereotaxic coordinates. San Diego: Academic.

Friedrich VL, Holstein GR, Li X, Gow A, Kelley KA, Lazzarini RA (1993) Intracellular distribution of transgenic bacterial $\beta$-galactosidase in central nervous system neurons and neuroglia. J Neurosci Res 36:88-98.

Goodman RH, Mandel G (1998) Activation and repression in the nervous system. Curr Opin Neurobiol 8:413-417.

Gunzburg WH, Salmons B, Zimmermann B, Muller M, Erfle V, Brem G (1991) A mammary-specific promoter directs expression of growth hormone not only to the mammary gland, but also to Bergman glia cells in transgenic mice. Mol Endocrinol 5:123-133.

Herbison AE, Fenelon VS (1995) Estrogen regulation of $\mathrm{GABA}_{\mathrm{A}}$ receptor subunit mRNA expression in preoptic area and bed nucleus of the stria terminalis of female rat brain. J Neurosci 15:2328-2337.

Hill RE, Favor J, Hogan BLM, Ton CCT, Saunders GF, Hanson IM, Prosser J, Jordan T, Hastie ND, van Heyningen V (1991) Mouse small eye results from mutations in a paired-like homeobox-containing gene. Nature 354:522-525.

Hogan B, Beddington R, Costantini F, Lacy E (1994) Manipulating the mouse embryo, a laboratory manual. Cold Spring Harbor, NY: Cold Spring Harbor Laboratory.

Hogan BLM, Horsburgh G, Cohen J, Hetherington CM, Fischer G, Lyon MF (1986) Small eye (Sey): a homozygous lethal mutation on chromosome 2 which affects the differentiation of both lens and nasal placodes in the mouse. J Embryol Exp Morphol 97:95-110.

Jennes L, Stumpf WE (1986) Gonadotropin-releasing hormone immunoreactive neurons with access to fenestrated capillaries in mouse brain. Neuroscience 18:403-416.

Lescheid DW, Terasawa E, Abler LA, Urbanski HF, Warby CM, Millar RP, Sherwood NM (1997) A second form of gonadotropin-releasing hormone $(\mathrm{GnRH})$ with characteristics of chicken GnRH-II is present in the primate brain. Endocrinology 138:5618-5629.

Livine I, Gibson MJ, Silverman A-J (1993) Biochemical differentiation and intercellular interactions of migratory gonadotropin-releasing hormone (GnRH) cells in the mouse. Dev Biol 159:643-656.

Mason AJ, Pitts SL, Nikolics K, Szonyi E, Wilcox JN, Seeburg PH, Stewart TA (1986) The hypogonadal mouse: reproductive functions restored by gene therapy. Science 234:1372-1378.

Min N, Joh TH, Kim KS, Peng C, Son JH (1994) 5' upstream DNA sequence of the rat tyrosine hydroxylase gene directs high-level and tissue-specific expression to catecholaminergic neurons in the central nervous system of transgenic mice. Mol Brain Res 27:281-289.

Moss RL, McCann SM (1973) Induction of mating behavior in rats by luteinizing hormone-releasing factor. Science 181:177-179.
Muske LE (1993) Evolution of gonadotropin-releasing hormone (GnRH) neuronal systems. Brain Behav Evol 42:215-230.

Norgren RB, Gao C (1994) LHRH neuronal subtypes have multiple origins in chickens. Dev Biol 165:735-738.

Northcutt RG, Muske LE (1994) Multiple embryonic origins of gonadotropin-releasing hormone $(\mathrm{GnRH})$ immunoreactive neurons. Dev Brain Res 78:279-290.

Pfaff DW (1973) Luteinizing hormone-releasing factor potentiates lordosis behavior in hypophysectomized ovariectomized female rats. Science 182:1148-1149.

Quanbeck C, Sherwood NM, Millar RP, Terasawa E (1997) Two populations of luteinizing hormone-releasing hormone neurons in the forebrain of the rhesus macaque during embryonic development. J Comp Neurol 380:293-309.

Rubenstein M, Liu B, Goodman RH, Low MJ (1992) Targeted expression of somatostatin in vasopressinergic magnocellular hypothalamic neurons of transgenic mice. Mol Cell Neurosci 3:152-161.

Schwanzel-Fukuda M, Pfaff DW (1989) Origin of luteinizing hormonereleasing neurons. Nature 338:161-164.

Schwanzel-Fukuda M, Garcia MS, Morrell JI, Pfaff DW (1987) Distribution of luteinizing hormone-releasing hormone in the nervus terminalis and brain of the mouse detected by immunocytochemistry. J Comp Neurol 255:231-244.

Sherwood NM, Lovejoy DA, Coe IR (1993) Origin of mammalian gonadotropin-releasing hormones. Endocr Rev 14:241-254.

Silverman A, Livne I, Witkin JW (1994) The gonadotrophin-releasing hormone (GnRH), neuronal systems: immunocytochemistry and in situ hybridization. In: The physiology of reproduction (Knobil E, Neill JD, eds), pp 1683-1706. New York: Raven.

Silverman AJ, Witkin JW, Millar RP (1990) Light and electron microscopic immunocytochemical analysis of antibodies directed against GnRH and its precursor in hypothalamic neurons. J Histochem Cytochem 38:803-813.

Spergel DJ, Krueth U, Hanley DF, Sprengel R, Seeburg PH (1997) $\mathrm{GnRH} /$ lacZ mice exhibit two major populations of beta-galactosidasestained neurons. Soc Neurosci Abstr 23:237.9.

Thieler K, Varnum DS, Stevens LC (1978) Development of Dickie's small eye, a mutation in the house mouse. Anat Embryol 155:81-86.

Tobet SA, Sower SA, Schwarting GA (1997) Gonadotropin-releasing hormone containing neurons and olfactory fibers during development: from lamprey to mammals. Brain Res Bull 44:479-486.

Waschek JA (1995) Transgenic targeting of neuroendocrine peptide genes in the hypothalamic-pituitary axis. Mol Neurobiol 10:205-217.

White RB, Eisen JA, Kasten TL, Fernald RD (1998) Second gene for gonadotropin-releasing hormone in humans. Proc Natl Acad Sci USA 95:305-309.

Wolfe AM, Wray S, Westphal H, Radovick S (1996) Cell-specific expression of the human gonadotropin-releasing hormone gene in transgenic animals. J Biol Chem 271:20016-20023.

Wray S, Gahwiler BH, Gainer H (1988) Slice cultures of LHRH neurons in the presence and absence of brainstem and pituitary. Peptides 9:1151-1175.

Wray S, Grant P, Gainer H (1989) Evidence that cells expressing luteinizing hormone-releasing hormone mRNA in the mouse are derived from progenitor cells in the olfactory placode. Proc Natl Acad Sci USA 86:8132-8136.

Wu TJ, Gibson MJ, Silverman AJ (1995) Gonadotropin-releasing hormone (GnRH) neurons of the developing tectum of the mouse. J Neuroendocrinol 7:899-902. 